\title{
VALUE ADDITION TO FROZEN DESSERTS THROUGH INCORPORATION OF PUMPKIN SOLIDS AND UF MILK PERMEATE
}

\author{
Fayed A.E., Abo El-Naga M.Y.", Khallaf M.F. and Marwa I. Eid \\ Food Sci. Dept., Fac. of Agric., Ain Shams Univ., P.O. Box 68, Hadayek Shoubra 11241, \\ Cairo, Egypt \\ *Corresponding author: mohamedyousef@agr.asu.edu.eg
}

Accepted 25 September, 2020

\begin{abstract}
Sherbet and Sorbet mixes were prepared to contain $9 \%$ fresh mango pulp, per se, $1 \%$ cooked pumpkin (CP). The water quantity required for both was replaced with ultrafiltrated milk permeate (UFMP) at the level of 25,50 or $75 \%$. The obtained results indicated that, separately, CP composed of higher moisture and total nitrogen, total phenolics (TP) as well as radical scavenging activity (RSA) values and lower total flavonoids (TF), carbohydrates contents than mango pulp. In both, Sherbet and Sorbet mixes, water substitution with UFMP was associated with increase in total solids, total and reducing sugars as well as ash contents. Neither acidity \%, nor $\mathrm{pH}$ values were significantly affected by the partial substitution of water with UFMP in Sherbet mix, although the acidity \% of Sorbet mix was significantly increased by UFMP addition. Freezing point of Sherbet or Sorbet mixes was gradually minimized by increasing the substitution level, although the flow behavior index was not influenced in Sherbet but increased in Sorbet mixes. The proportional increment of UFMP level in mix was associated with gradually considerable increase in its consistency coefficient, apparent as well as dynamic viscosities, TP and RSA values of both Sorbet and Sherbet mixes. UFMP led to increase in the specific gravity of mixes before and after freezing as well as elevated the overrun and strengthened the melting resistance of the final product. Furthermore, the frozen dessert of $75 \%$ UFMP, whether being Sherbet or Sorbet gained the highest panelists scores for all sensory attributes. It could be concluded that, it could successfully produce a product that meets the intended health purposes based on the substitution of $10 \%$ of mango pulp with pumpkin
\end{abstract}

solids of many impressive health benefits as well as the utilization of ultrafiltration milk permeate as a source of the essential electrolytes instead of $75 \%$ of required water en route to innovate frozen desserts such as Sherbet and Sorbet.

Keywords: Frozen desserts; Sherbet; Sorbet; Antioxidant activity; Physiochemical and Rheological properties

\section{INTRODUCTION}

Ultrafiltration (UF) of milk produces a large quantity of permeate as by-product. The dairy industry generates significant liquid waste; whose disposal requires a large amount of capital investment. The permeate contains Lactose as the major constituent in addition to water soluble vitamins and the soluble salts of milk (Dragana et al 2013). Therefore, UF-milk permeate (UFMP) can be considered a nutritive food ingredient. UFMP poses a problem for dairy industries in its disposal as a source of environmental pollution, because of its associated high biological oxygen demand (Fayed, 1986). UFMP is comprised primarily of lactose (5\%), water $(93 \%)$, and considered as a source of high quality vitamins and minerals which are important for human health. UFMP contains electrolytes such as sodium, potassium, magnesium, zinc and calcium. Great attentions were directed for utilizing UFMP in the production of many useful products, such as for sports drinks (Hattem et al 2010).

Mango fruit contains several bioactive principles, viz. polyphenols, flavonoids, carotenoids and ascorbic acid having different beneficial properties because of their antioxidant activities (Muralidhara et al 2019). On the other hand, pumpkin refers to 
Cucurbita pepo, an orange type of winter squash. While commonly viewed as a vegetable, pumpkin is scientifically a fruit, as it contains seeds. Beyond its delicious taste, pumpkin is nutritious and linked to several health benefits (Gong et al 2012). Where, pumpkin is high in vitamins and minerals, at the same time low in calories. Pumpkin is also a great source of antioxidants, $\alpha$-carotene and $\beta$-carotene, a carotenoid that gets converted in the body into vitamin $A$, along with lutein and zeaxanthin. These are beneficial in protecting eyes against sight loss and can help keep the skin strong and healthy; i.e. acts as a natural sunblock (Pullar et al 2017). Pumpkin contains $\beta$-kryptoxanthin which may protect cells against damage by free radicals (Khansari et al 2009). These compounds are linked to lower risks of stomach, throat, pancreas and breast cancers (Zhou et al 2016). It is also a good source of vitamin $C$ that can help boost the immune system. Its supply of vitamin E, iron and folate may strengthen the immunity (Veldhoen and Ferreira, 2015). Pumpkin also supplies dietary fiber which have impact on gut health (Vinceti et al 2016).

Out of the total frozen desserts produced in 2000 in the United States, about 1.5 billion gallons, Sherbets and ices comprised about 3.6 and $4.3 \%$, respectively. Sherbets made up about $1 \%$ of the soft-serve products. Also in 2000 in Canada, where total annual production of frozen desserts is about 323 million liters, Sherbets and water ices comprise about 3.4 and $4.8 \%$, respectively. These products are in great demand in the summer months (Marshall et al 2003).

A Sherbet is frozen foam made from water, nutritive sweeteners, fruit or fruit flavoring, fruit acid, milk solids, stabilizer, and coloring. Sherbets contain $1-2 \%$ milk fat (no other fat permitted) and at least $1 \%$ non-fat milk solids (NFMS) with the total milk solids between 2 and 5\% (Code of Federal Regulations "CFR", 2018). Standards in other countries may vary; e.g., in Canada maximum of $5 \%$ milk solids, including milkfat is permitted. This acidic food, when characterized by a fruit flavor, has a minimal titratable acidity of $0.35 \%$ calculated as lactic acid (Marshall et al 2003).

Ices or water ices, sometimes called Italian ices, have essentially the composition similar to that of Sherbets, except that they do not contain any milk solids and egg ingredient, except for egg white. They are frozen and simultaneously whipped to contain overrun ranging from 0 (quiescently frozen bars) to $30 \%$ (dynamically frozen items). Sorbets are an upscale version of ices in that they contain fruit, fruit juices and/or fruit extracts rather than imitation flavorings. Sherbets and water ices are defined foods (Code of Federal Regulations "CFR", 2018), but Sorbets are not a defined food in the United States.

The objective of this study was to fruitfully utilize a rich source of the essential electrolytes, namely UFMP as well as impressive health benefits of pumpkin in producing Sherbet and Sorbet (true fruit flavored water ice) using fresh mango pulp en route to innovate functional products.

\section{MATERIALS AND METHODS}

\section{Materials}

Skimmed milk powder (3.8 \% moisture, 34\% protein, $1.5 \%$ fat and $8.3 \%$ ash). was obtained from Synlait Milk Ltd., Rakaia 7783 - New Zealand. Ultrafiltered milk permeate (UFMP) was obtained from Animal Production Research Institute, Agricultural Research Center, Giza, Egypt. Mango fruit (Mangifira indica), variety Zebdia, were purchased from ElObour market, El-Obour City, Qalyoubia governorate, Egypt. Fresh pumpkin fruit (Cucurbita pepo) were obtained from local market, El-Sheikh Zayed city, Giza governorate, Egypt. Commercial grade granulated cane sugar produced by Sugar and Integrated Industries Co. at Hawamdia, Giza governorate, Egypt. Sodium carboxy methylcellulose (CMC); made by BDH chemicals Ltd poole; England, was obtained from the local market. Citric acid was obtained from El-Gomhouria Co. for Drugs and Medical Supplies, Cairo, Egypt.

\section{Experimental procedures}

\section{Preparation of mango pulp}

Mango fruit (Mangifira indica) were washed and then peeled. Seeds were removed to get the mango pulp, which was blended to obtain a homogenous product. Pulp yield reached $60-65 \%$ of fruit weight.

\section{Preparation of cooked pumpkin cubes}

Pumpkin (Cucurbita pepo) fruit (ca $4 \mathrm{~kg}$ ) was washed and cut into 2 halves; the seeds were removed. The peeled pumpkin fruit was portioned into small cubes of equal size ( $c a$ one $\mathrm{cm}^{3}$ ) and cooked in hot water at $90^{\circ} \mathrm{C}$ for $5 \mathrm{~min}$. Thereafter, cooked pumpkin cubes were cooled to $\mathrm{ca} 4^{\circ} \mathrm{C}$. 

solids and uf milk permeate

Preparation of mango Sherbet replaced with $10 \%$ (cooked pumpkin and mango pulp) made using milk permeate instead of water with different levels

The manufacturing procedure was carried out as described by Marshall et al (2003) and provided by EOSQ (2005a). Sherbet base mix (the control) was prepared to contain $5 \%$ milk solids not fat, $9 \%$ mango pulp, $1 \%$ cooked pumpkin, $25 \%$ sucrose, $0.2 \%$ CMC and $59.5 \%$ potable water (Table, 1 ). The water portion of mix was replaced with UFMP at levels of 25,50 or $75 \%$ and mixed well. All the mixes were blended for $5 \mathrm{~min}$, heat treated at $85^{\circ} \mathrm{C}$ for 5 min. and then cooled to $5^{\circ} \pm 1^{\circ} \mathrm{C}$ and aged at this temperature for $48 \mathrm{~h}$. Thereafter, each aged mix was frozen in an experimental ice cream batch freezer at $-18^{\circ} \mathrm{C}$. The ice cream freezer (Taylor, Model, 103) is automatically controlled to stop whipping after 18-20 minutes, when ice cream was frozen.

Table 1. Recipe of mango Sherbet replaced with 10 $\%$ cooked pumpkin (CP) made using ultrafiltered milk permeate (UFMP) in place of water at varying levels

\begin{tabular}{|c|c|c|c|c|}
\hline \multirow{2}{*}{$\begin{array}{c}\text { Ingredient } \\
\text { (g) }\end{array}$} & \multicolumn{4}{|c|}{ Water replacement level with UFMP } \\
\cline { 2 - 5 } & $\begin{array}{c}\text { Nil } \\
\text { (control) }\end{array}$ & $\mathbf{2 5 \%}$ & $\mathbf{5 0 \%}$ & $\mathbf{7 5 \%}$ \\
\hline $\begin{array}{c}\text { Skim milk } \\
\text { powder }\end{array}$ & 53.00 & 53.00 & 53.00 & 53.00 \\
Mango & 90.00 & 90.00 & 90.00 & 90.00 \\
pulp & & & & \\
CP & 10.00 & 10.00 & 10.00 & 10.00 \\
Sucrose & 250.00 & 250.00 & 250.00 & 250.00 \\
CMC & 2.00 & 2.00 & 2.00 & 2.00 \\
UFMP & 0.00 & 148.725 & 297.450 & 446.175 \\
Water & 595.000 & 446.275 & 297.550 & 148.825 \\
Total & 1000 & 1000 & 1000 & 1000 \\
\hline
\end{tabular}

The air pressure in compressor unit was adjusted to be in the range of 3-4 bar absolute pressure. The frozen product was drawn from the freezer in the soft form at approximately $-7^{\circ} \mathrm{C}$. The resultant product was filled into PVC cups (cap. 100 $\mathrm{ml}$ ) covered with lid and hardened in a deep freezer at $-20^{\circ} \mathrm{C}$ for $24 \mathrm{~h}$ prior to analyses. Three replicates were done for every treatment.
Preparation of mango Sorbet (true fruit flavored water ice) replaced with $10 \%$ cooked pumpkin containing UFMP to replace water portion of mix at varying levels

The manufacturing of Sorbet (fruit flavored water ice) was carried out as detailed by Marshall et al (2003) and EOSQ (2005b). Sorbet base mix (control) was prepared to contain $9 \%$ mango pulp, $1 \%$ cooked pumpkin cubes, 30\% sucrose, $0.2 \% \mathrm{CMC}$, $0.01 \%$ citric acid and $59.79 \%$ potable water (Table, 2). The water portion of mix was replaced with UFMP at the same levels, as previously done for Sherbet mixes (i.e. 25, 50 and $75 \%$ ). All the mixes were processed as mentioned under Experimental procedures; three replicates were carried out.

Table 2. Recipe of mango Sorbet replaced with $10 \%$ cooked pumpkin (CP) made using ultrafiltered milk permeate (UFMP) instead of water with different levels

\begin{tabular}{|c|c|c|c|c|}
\hline \multirow{2}{*}{$\begin{array}{c}\text { Ingredient } \\
\text { (g) }\end{array}$} & \multicolumn{4}{|c|}{ Water replacement level with UFMP } \\
\cline { 2 - 5 } & $\begin{array}{c}\text { Nil } \\
\text { (control) }\end{array}$ & $\mathbf{2 5 \%}$ & $\mathbf{5 0 \%}$ & $\mathbf{7 5 \%}$ \\
\hline $\begin{array}{c}\text { Mango } \\
\text { pulp } \\
\text { CP }\end{array}$ & 90.00 & 90.00 & 90.00 & 90.00 \\
Sucrose & 300.00 & 10.00 & 10.00 & 10.00 \\
CMC & 2.00 & 2.00 & 2.00 & 2.00 \\
Citric acid & 0.10 & 0.10 & 0.10 & 0.10 \\
UFMP & - & 149.475 & 298.95 & 448.425 \\
Water & 597.90 & 448.425 & 298.95 & 149.475 \\
Total & 1000 & 1000 & 1000 & 1000 \\
\hline
\end{tabular}

Analytical methods

Total solids, fat, total nitrogen, fiber and ash contents of Sherbet and Sorbet mixes were determined according to AOAC (2012). Titratable acidity (TA) \% was determined as citric acid according to AOAC (2012). The total sugars content was determined according to phenol-sulphuric acid method as described by Charles (2010). Reducing sugars content was determined according to AOAC (2012). Electron-donating ability was determined by implying 2,2-diphenyl-1-picrylhydrazyl (DPPH) radicalscavenging assay as described by Brand-Williams et al (1995). The total phenolic content was calorimetrically determined, using the Folin-Ciocalteu 
method, as described by Singleton et al (1999). The total flavonoid contents were determined according to the method of Mohdaly et al (2012).

The $\mathrm{pH}$ value of the sorbet and sherbet mixes was measured electrometrically using Lab. $\mathrm{pH}$ meter with a glass electrode, Hanna model 8417 digital $\mathrm{pH}$ meter at $20^{\circ} \mathrm{C}$ after calibrating with fresh $\mathrm{pH} 4.0$ and 7.0 standard buffers according to the methods of BSI (1990). The specific gravity of the mix and the final frozen product was determined according to Sommer (1951). Freezing point of mix was measured in accordance with FAO (1977) using a Digital Probe Thermometer $\left(-40\right.$ to $\left.+200^{\circ} \mathrm{C}\right)$ with probe 125 $\mathrm{mm}$ (according to HACCP), TFA Dostmann, $\mathrm{GmbH}$ \& Co. KG, Wertheim, Germany. The overrun per cent was calculated as mentioned per Goff and Hartel (2013) from the figures obtained for the specific gravity (Sp. gr.) of the mix and that of the resultant frozen product using the following equation:

Overrun $\%=\frac{\text { Sp.gr.of mix }- \text { Sp.gr.of frozen product }}{\text { Sp.gr.of frozen product }} \times 100$

The melting resistance of the hardened frozen product was determined as described by Muse and Hartel (2004).

\section{Measurement of rheological properties}

Rheological properties of Sherbet and Sorbet mixes were measured at $10 \pm 1^{\circ} \mathrm{C}$ using a rotary coaxial Rheometer (RHEOTEST, type 2, Medingn, German) (Toledo 2007). The liquid samples were loaded in the outer cylinder (S) and then subjected to rotational shearing using the cylindrical spindles (S1) and (S2) of the Rheometer. The samples were sheared between shear rate of 0.33 to1342 $\mathrm{s}^{-1}$ or of 3 to $427 \mathrm{~s}^{-1}$ according to the type and consistency of the tested solutions. The rotation speeds and torque values of the Rheometer were converted to shear rate and shear stress (dynes $/ \mathrm{cm}^{2}$ ) according to the operating manual of the Rheometer. All parameters were calculated from the descending flow curve to express the data corresponding the well stirred product. Consistency coefficient was calculated using the following equation:

$$
\log \delta=\log \kappa+n \log \gamma
$$

Where:

$\delta=$ Shearing stress, $\gamma=$ shearing gradient or shear rate, $\mathrm{n}=$ Flow behavior index and $\kappa=$ consistency coefficient or consistency index

Whilst, the yield value or yield stress was calculated by fitting the shear stress-shear rate data to the Casson equation (Bourne, 1982):

$$
\sqrt{\delta=} \sqrt{\delta o}+\eta a \sqrt{\gamma}
$$

Where:

$\delta=$ Shearing stress, $\delta 0=$ yield stress,

$\eta_{\mathrm{a}}=$ apparent viscosity and $\gamma=$ shear rate

The dynamic viscosity of mixes was measured as described by Toledo (2007), at shear rate $437 \mathrm{~s}^{-}$ 1 . The Sherbet and Sorbet mixes were tempered to $10 \pm 1^{\circ} \mathrm{C}$ before loading them in the viscometer device.

Scoring of frozen desserts was carried out by the staff members of Food Sci. Dept., Fac. of Agric., Ain Shams Univ. according to Rothwell (1960). The maximum score were 40 points for consistency, 50 points for flavor and 10 points for melting quality.

The data obtained were subjected to statistical analysis according to statistical analyses system user's guide (SAS, 2006) using General Linear Model (GLM) with main effect of treatments. Duncan's multiple range was used to differentiate the treated samples among of three replicates at $\mathrm{P} \leq$ 0.05 .

\section{RESULTS AND DISCUSSION}

Physicochemical properties of the main ingredients used in of Sherbet or Sorbet mix

As could be observed in Table 3 cooked pumpkin was distinguished from mango for its higher value of total phenolics as well as DPPH radical scavenging activity and lower total flavonoids. Lotfy et al (2017) reported that, pumpkin seems to be promising as antioxidants containing food. These results of cooked pumpkin are in coincidence with those found by Rizk (2016). Mango attributes were as in Muralidhara et al (2019). The UFMP properties agree with those found by Fayed (1986) and Aamer et al (2017). While, those of skimmed milk powder are in accordance to Fayed (1986). 
Table 3. Chemical properties of main ingredients used for making Sherbet and Sorbet mixes

\begin{tabular}{|c|c|c|c|c|}
\hline \multirow{2}{*}{ Property } & \multicolumn{3}{|c|}{ Ingredient } & \multirow[b]{2}{*}{$\begin{array}{c}\text { Skim } \\
\text { milk } \\
\text { powder }\end{array}$} \\
\hline & $\begin{array}{c}\text { Mango } \\
\text { pulp }\end{array}$ & $\begin{array}{c}\text { Cooked } \\
\text { pumpkin }\end{array}$ & $\begin{array}{c}\text { Milk } \\
\text { permeate }\end{array}$ & \\
\hline Moisture\% & $83.42^{\mathrm{c}}$ & $91.39^{b}$ & $94.32^{\mathrm{a}}$ & $4.20^{d}$ \\
\hline Total nitrogen\% & $0.128^{c}$ & $0.318^{b}$ & $0.021^{d}$ & $5.56^{a}$ \\
\hline Fat\% & 0.36 & 0.78 & 0.00 & 1.00 \\
\hline Ash\% & $0.33^{b}$ & $0.31^{b}$ & $0.15^{\mathrm{c}}$ & $8.50^{\mathrm{a}}$ \\
\hline Fiber\% & 1.50 & 1.35 & 0.00 & 0.00 \\
\hline $\begin{array}{l}\text { Carbohy- } \\
\text { drates } \%\end{array}$ & $13.59^{b}$ & $4.26^{c}$ & $5.40^{\circ}$ & $51.00^{a}$ \\
\hline $\begin{array}{l}\text { Total phenolics } \\
\text { (mgGAE/g) }\end{array}$ & $33.00^{\mathrm{b}}$ & $530.32^{a}$ & $5.55^{d}$ & $22.91^{\mathrm{C}}$ \\
\hline $\begin{array}{l}\text { Total flavonoids } \\
\text { (mg QE /g) }\end{array}$ & $264.00^{a}$ & $17.24^{b}$ & $0.49^{d}$ & $8.30^{c}$ \\
\hline $\begin{array}{c}\text { DPPH radical } \\
\text { scavenging ac- } \\
\text { tivity } \%\end{array}$ & $18.66^{c}$ & $61.69^{b}$ & $18.50^{c}$ & $97.63^{a}$ \\
\hline
\end{tabular}

* Calculated by difference GAE: Gallic acid equivalent QE: Quercetin Equivalent

DPPH: 2, 2-diphenyl-1-picrylhydrazyl

The means with the same letter at any position did not significantly differ $(P>0.05)$.

\section{Physicochemical characteristics of Sherbet or Sorbet mixes}

The results of Table 4 reveal that, an increase in the replacement of water portion of mixes with UFMP, lead to significantly $(P<0.05)$ higher total solids (TS) in the resultant Sherbet or Sorbet mixes. A replacement level of $75 \%$ with UFMP elevated the TS level to 1.15 fold for Sherbet and 1.10 fold for Sorbet. At replacement level of $25 \%$ and $50 \%$ UFMP, the increases in TS level were 1.06 and 1.09 fold for both the products. The Sherbet mix composition agrees with that approved by EOSQ (2005a), while that of Sorbet mix agrees with that approved by EOSQ (2005b). There was hardly any variation in the TS between Sherbet and Sorbet mixes, since the relatively lower sugar content in sherbet mix (25.0\%) versus Sorbet was compensated by $5 \%$ milk powder added in the recipe of their mixes. (Tables, 2 and 3).

Similar trend was noted when total sugar content was taken into consideration. When dealing with reducing sugar content of Sherbet mixes, there was an increase $(\mathrm{P}<0.05)$ in such component by $1.24,1.49$ and 1.74 fold (versus control) when the level of water replaced with UFMP were 25, 50 and
$75 \%$ respectively. Similar trend was noticed when total as well as reducing sugar content of Sorbet was taken into account. In case of Sorbet mixes, the increase $(\mathrm{P}<0.05)$ in the reducing sugar content were 1.94, 2.94 and 3.93 fold at water replacement ratio with UFMP of 25,50 and $75 \%$ respectively. It is worthy to mention that, at any specific water substitution level with UFMP, the Sherbet had lower total sugar $(\mathrm{P}<0.05)$ but higher reducing sugar content $(\mathrm{P}<0.05)$ (versus Sorbet) at the respective substitution level (Table, 4).

Ash content was increased linearly with increasing level of UFMP used to replace water portion of Sherbet or Sorbet mixes. This effect was marked from $50 \%$ level of replacement. The ash content of Sherbets was significantly $(P<0.05)$ raised by 0.07 and $0.14 \%$ at replacement level of water with UFMP at $50 \%$ and $75 \%$, respectively. The increasing level of ash in Sorbet comply with the substitution level of water portion of mix with UFMP and it reached 1.29, 1.80 and 3.00 fold versus control product at replacement level being 25, 50 and $75 \%$, respectively (Table, 4).

Neither acidity nor the $\mathrm{pH}$ value was significantly $(P>0.05)$ affected by substitution of water with UFMP in case of Sherbet mixes. The acidity was around $0.3 \%$ citric acid, while $\mathrm{pH}$ value was around 5.0. In case of Sorbet, the acidity was significantly $(P<0.05)$ higher in product having greater level of water replaced by UFMP in the mixes. The $\mathrm{pH}$ value was not markedly affected by such replacement of water portion of mixes with UFMP (Table, 4).

A gradual increase $(P<0.05)$ in the specific gravity of mixes was noted with an increasing level of water replacement with UFMP in the case of both Sherbet and Sorbet mixes. The Sorbet mix had invariably lower $(P<0.05)$ specific gravity values, noted at specified replacement level of water with UFMP, when compared with that of Sherbet mix.

The data depicted in Table 4 revealed that freezing point of mixes recorded -3.4 and $-3.1^{\circ} \mathrm{C}$ for control samples of sherbet and sorbet mixes, respectively. The difference in freezing point between the two tested products could be referred to their content in reducing sugar. The higher the reducing sugar content, the lower will be the freezing point, since the depression in freezing point depends more on the component of lower molecular weight (reducing sugars and salts) rather than those of higher molecular weight (Disaccharides). The freezing point got depressed with increasing substitution level of water portion of mixes with UFMP. was; the F.P. was $-4.7^{\circ} \mathrm{C}$ for Sherbet or $-4.5^{\circ} \mathrm{C}$ for Sorbet mixes at $75 \%$ level of replacement. That reflects the 
load of true soluble sugars (sucrose and fruit sugar and additionally permeate lactose in case of Sorbet, besides the further SMP lactose in the case of Sherbets) and salts in the medium. This phenomenon is, indeed, logically with regard to the proportional increment in both reducing sugar as well as ash content of Sherbet and Sorbet mixes with increasing substitution level of water portion of mixes with UFMP (Table, 3).

The curves illustrated in (Fig. 1). Demonstrate the extent of the correlation in the ascending relationship between the level of replacement of water with UFMP, whether of Sherbets or Sorbets, and the level of the total dissolved components and their inverse relationship with the freezing point of the mix. With increasing proportion of water substitution with UFMP in the mixes there was a linear increment $(\mathrm{P}<0.05)$ in total sugar and ash content. This resulted in decline in the freezing point of mix. Similar findings have been reported and discussed by (Fayed et al 2012) in their frozen products mentioned above. It is noteworthy to mention that even at nearly similar TS level, Sherbet mixes were associated with lower FP as compared to Sorbets, even when compared at each specific level of water substitution with UFMP, as is illustrated in Fig. 1.

\section{Rheological properties of Sherbet or Sorbet mix}

The rheological results given in Table 5 declared that, although the flow behavior index of Sherbet mix was not influenced by the level of water replaced with UFMP, the control Sorbet mix (without UFMP) showed the least value of $(n)$ being 0.3895 . Contrary, to the observed effect for Sherbet, the value of flow behavior index of Sorbet gradually increased to 0.5651 , when UFMP replaced water portion of mix at $75 \%$ level. The proportional increment of water substitution with UFMP in Sherbet or Sorbet mixes was associated with gradual but considerable increase in their consistency coefficient, apparent and dynamic viscosities. This is due to the added solids as more UFMP was added (Table, 4). Similar findings have been reported and discussed by (Fayed et al 2012). The results obtained in Table 5 revealed that, addition of UFMP increased the viscosity, and consequently the mouth feel, of resultant frozen Sherbets as will be clearly correlated to the sensory evaluation results. Sherbet mixes were always distinguished with higher
$(P<0.05)$ value either of consistency coefficients, apparent or dynamic viscosity versus Sorbet at any specified UFMP level as replacement of water portion of mixes (Table, 5). Moreover, the flow behavior indices $(n)$ were in the range 0.5525 to 0.5405 , indicating the pseudo plastic pattern of Sherbet mixes. This explains the clear convergence in the slope of the flow behavior curves (Fig. 2) in comparison with those of Sorbet mixes as shown in (Fig. 3), where the relationship between shear rate and shear stress was non-linear indicating the non-Newtonian behavior of the experimental Sorbet mixes.

\section{Physical properties of Sherbet or Sorbet}

Table 6 indicates that the specific gravity of control Sherbet mix was 0.6980 ; such value tended to increase gradually to $0.7660,0.7906$ or 0.8633 for replacement level of water with UFMP of 25,50 and $75 \%$ respectively. Likewise, significant $(P<0.05)$ increase in the specific gravity of frozen Sorbet was noted. The rise was by $1.11,1.26$ or 1.30 fold when the water portion of mix was replaced with UFMP at 25,50 , and $75 \%$, respectively. This phenomenon could be ascribed to the increase in solids contained in UFMP as against water (only total dissolved solids part) (Table, 3).

The products, whether Sherbet or Sorbet mixes prepared using UFMP at increasing level of replacement of water portion of mixes, were associated with significantly $(P<0.05)$ higher overrun. The overrun in sherbet mixes was 1.22 fold higher when UFMP was used to replace water at $75 \%$ level. The increase in overrun in Sherbet was 1.08 and 1.16 fold when the replacement level of water with UFMP at the levels of 25 and $50 \%$ respectively. In case of Sorbet too, the overrun obtained was significantly $(\mathrm{P}<0.05)$ greater in product made using greater replacement of water with UFMP. The overrun in control and experimental product $(75 \%$ replacement with UFMP) was $25.12 \%$ and $30.24 \%$ respectively; an increase of 1.20 fold over control product. The increase in the overrun in Sherbet and Sorbet mixes containing UFMP at higher values of replacement level for water portion of mix, can be explained by the increased viscosity of such mixes (Table 5). Fayed et al (2012) reported that, in most cases, there is a direct relationship between the viscosity of the mixture and the overrun in the product made from. 

solids and uf milk permeate

Table 4. Physicochemical properties of mango Sherbet or Sorbet mixes fortified with $1 \%$ cooked pumpkin as affected by water replacement level with ultrafiltered milk permeate (UFMP)

\begin{tabular}{|c|c|c|c|c|c|c|c|c|}
\hline \multirow{2}{*}{ Property } & \multicolumn{5}{|c|}{ Water replacement level with ultrafiltered milk permeate } \\
\cline { 2 - 8 } & \multicolumn{2}{|c|}{ Nil (Control) } & \multicolumn{2}{|c|}{$25 \%$} & \multicolumn{2}{|c|}{$50 \%$} & \multicolumn{2}{c|}{$75 \%$} \\
\cline { 2 - 9 } & Sherbet & Sorbet & Sherbet & Sorbet & Sherbet & Sorbet & Sherbet & Sorbet \\
\hline Total solids (\%) & $31.38^{\mathrm{d}, \mathrm{a}}$ & $32.81^{\mathrm{d}, \mathrm{a}}$ & $33.13^{\mathrm{c}, \mathrm{a}}$ & $33.06^{\mathrm{c}, \mathrm{a}}$ & $34.42^{\mathrm{b}, \mathrm{a}}$ & $34.08^{\mathrm{b}, \mathrm{a}}$ & $36.00^{\mathrm{a}, \mathrm{a}}$ & $35.96^{\mathrm{a}, \mathrm{a}}$ \\
Total Sugars (\%) & $29.00^{\mathrm{d}, \mathrm{b}}$ & $31.45^{\mathrm{d}, \mathrm{a}}$ & $30.18^{\mathrm{c}, \mathrm{b}}$ & $32.78^{\mathrm{c}, \mathrm{a}}$ & $30.62^{\mathrm{b}, \mathrm{b}}$ & $33.14^{\mathrm{b}, \mathrm{a}}$ & $31.93^{\mathrm{a}, \mathrm{b}}$ & $34.43^{\mathrm{a}, \mathrm{a}}$ \\
Reducing sugars (\%) & $3.35^{\mathrm{d}, \mathrm{a}}$ & $0.85^{\mathrm{d}, \mathrm{b}}$ & $4.15^{\mathrm{c}, \mathrm{a}}$ & $1.65^{\mathrm{c}, \mathrm{b}}$ & $5.00^{\mathrm{b}, \mathrm{a}}$ & $2.50^{\mathrm{b}, \mathrm{b}}$ & $5.84^{\mathrm{a}, \mathrm{a}}$ & $3.34^{\mathrm{a}, \mathrm{b}}$ \\
Ash (\%) & $0.394^{\mathrm{d}, \mathrm{a}}$ & $0.033^{\mathrm{d}, \mathrm{b}}$ & $0.395^{\mathrm{c}, \mathrm{a}}$ & $0.055^{\mathrm{c}, \mathrm{b}}$ & $0.463^{\mathrm{b}, \mathrm{a}}$ & $0.077^{\mathrm{b}, \mathrm{b}}$ & $0.527^{\mathrm{a}, \mathrm{a}}$ & $0.099^{\mathrm{a}, \mathrm{b}}$ \\
Acidity (\%) & $0.31^{\mathrm{a}, \mathrm{b}}$ & $0.36^{\mathrm{a}, \mathrm{a}}$ & $0.31^{\mathrm{a}, \mathrm{a}}$ & $0.31^{\mathrm{a}, \mathrm{a}}$ & $0.29^{\mathrm{b}, \mathrm{a}}$ & $0.26^{\mathrm{c}, \mathrm{a}}$ & $0.28^{\mathrm{b}, \mathrm{a}}$ & $0.21^{\mathrm{d}, \mathrm{a}}$ \\
pH value & $4.71^{\mathrm{a}, \mathrm{a}}$ & $4.83^{\mathrm{a}, \mathrm{a}}$ & $4.76^{\mathrm{a}, \mathrm{a}}$ & $4.96^{\mathrm{a}, \mathrm{a}}$ & $4.87^{\mathrm{a}, \mathrm{b}}$ & $5.10^{\mathrm{a}, \mathrm{a}}$ & $4.98^{\mathrm{a}, \mathrm{a}}$ & $5.18^{\mathrm{a}, \mathrm{a}}$ \\
Specific gravity & $0.957^{\mathrm{d}, \mathrm{a}}$ & $0.747^{\mathrm{d}, \mathrm{b}}$ & $1.074^{\mathrm{c}, \mathrm{a}}$ & $0.832^{\mathrm{c}, \mathrm{b}}$ & $1.132^{\mathrm{b}, \mathrm{a}}$ & $0.954^{\mathrm{b}, \mathrm{a}}$ & $1.254^{\mathrm{a}, \mathrm{a}}$ & $1.008^{\mathrm{a}, \mathrm{a}}$ \\
Freezing point $\left({ }^{\circ} \mathrm{C}\right)$ & $-3.4^{\mathrm{a}, \mathrm{a}}$ & $-3.1^{\mathrm{a}, \mathrm{a}}$ & $-3.8^{\mathrm{b}, \mathrm{a}}$ & $-3.6^{\mathrm{b}, \mathrm{a}}$ & $-4.3^{\mathrm{c}, \mathrm{a}}$ & $-4.1^{\mathrm{c}, \mathrm{a}}$ & $-4.7^{\mathrm{d}, \mathrm{a}}$ & $-4.5^{\mathrm{d}, \mathrm{a}}$ \\
\hline
\end{tabular}

The letters before comma possess the factor of water replacement with UFMP. While those after comma possess the factor of the kind of dairy frozen dessert mix, respectively. The means with the same letter at any position did not significantly differ $(P>0.05)$.

Table 5. Rheological parameters of mango Sherbet or Sorbet mixes fortified with $1 \%$ cooked pumpkin as affected by water replacement level with ultrafiltered milk permeate (UFMP)

\begin{tabular}{|c|c|c|c|c|c|c|c|c|}
\hline \multirow{3}{*}{ Parameter } & \multicolumn{8}{|c|}{ Water replacement level with ultrafiltered milk permeate } \\
\hline & \multicolumn{2}{|c|}{ Nil (Control) } & \multicolumn{2}{|c|}{$25 \%$} & \multicolumn{2}{|c|}{$50 \%$} & \multicolumn{2}{|c|}{$75 \%$} \\
\hline & Sherbet & Sorbet & Sherbet & Sorbet & Sherbet & Sorbet & Sherbet & Sorbet \\
\hline $\begin{array}{l}\text { Consistency coefficient } \\
\qquad\left(\mathrm{K} \text {, dyne } . \mathrm{s}^{\mathrm{n}} / \mathrm{cm}^{2}\right)\end{array}$ & $17.47^{\mathrm{d}, \mathrm{a}}$ & $7.22^{\mathrm{d}, \mathrm{b}}$ & $19.01^{\mathrm{c}, \mathrm{a}}$ & $7.73^{\mathrm{c}, \mathrm{a}}$ & $20.98^{\mathrm{b}, \mathrm{a}}$ & $10.76^{\mathrm{b}, \mathrm{b}}$ & $23.31^{\mathrm{a}, \mathrm{a}}$ & $14.15^{\mathrm{a}, \mathrm{b}}$ \\
\hline Flow behavior index $(n)$ & $0.5525^{\mathrm{a}, \mathrm{a}}$ & $0.3895^{\mathrm{d}, \mathrm{b}}$ & $0.5467^{\mathrm{a}, \mathrm{a}}$ & $0.4586^{c, b}$ & $0.5647^{a, a}$ & $0.5262^{a, b}$ & $0.5405^{a, b}$ & $0.5651^{\mathrm{a}, \mathrm{a}}$ \\
\hline $\begin{array}{c}\text { Correlation coefficient } \\
\text { square }\end{array}$ & 0.9988 & 0.9384 & 0.9993 & 0.9482 & 0.9996 & 0.9847 & 0.9992 & 0.9923 \\
\hline $\begin{array}{l}\text { Apparent viscosity } \\
\left(\eta_{a}, \text { dyne } . s^{n-1} / \mathrm{cm}^{2}\right)\end{array}$ & $1.251^{\mathrm{c}, \mathrm{a}}$ & $0.3458^{\mathrm{c}, \mathrm{b}}$ & $1.272^{\mathrm{c}, \mathrm{a}}$ & $0.400^{c, b}$ & $1.340^{\mathrm{b}, \mathrm{a}}$ & $0.4337^{b, b}$ & $1.427^{\mathrm{a}, \mathrm{a}}$ & $0.513^{a, b}$ \\
\hline Dynamic viscosity (cP) & $125.13^{\mathrm{d}, \mathrm{a}}$ & $34.58^{\mathrm{d}, \mathrm{b}}$ & $127.20^{\mathrm{c}, \mathrm{a}}$ & $40.00^{c, b}$ & $134.11^{\mathrm{b}, \mathrm{a}}$ & $43.37^{\mathrm{b}, \mathrm{b}}$ & $142.65^{\mathrm{a}, \mathrm{a}}$ & $51.30^{a, b}$ \\
\hline
\end{tabular}




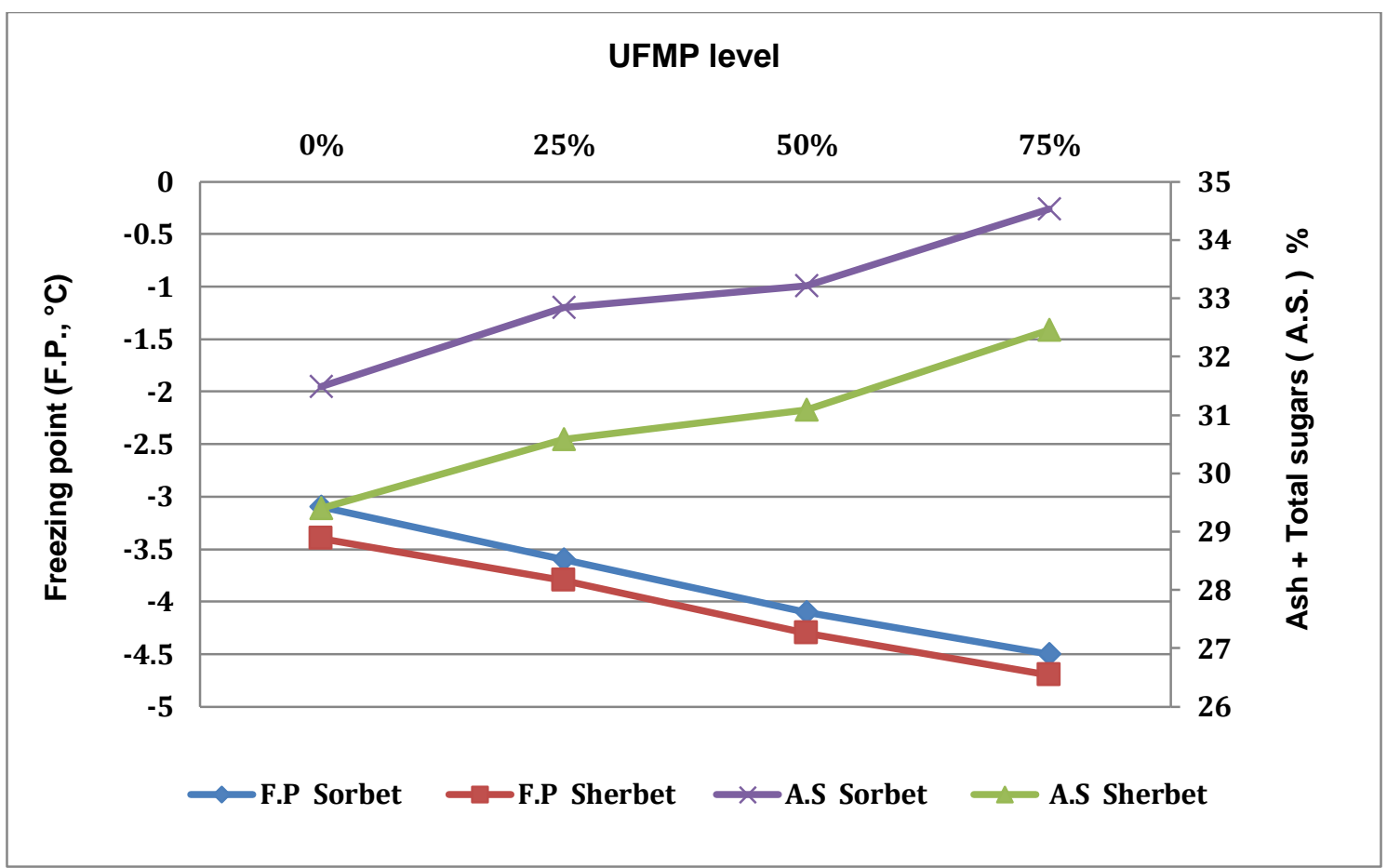

Fig. 1. Graph representing freezing point (F.P.) versus soluble mix component (ash plus total sugars, A.S.) content of mango Sherbets and / or Sorbets mixes with $1 \%$ cooked pumpkin as affected by water replacement level with ultrafiltered milk permeate (UFMP)

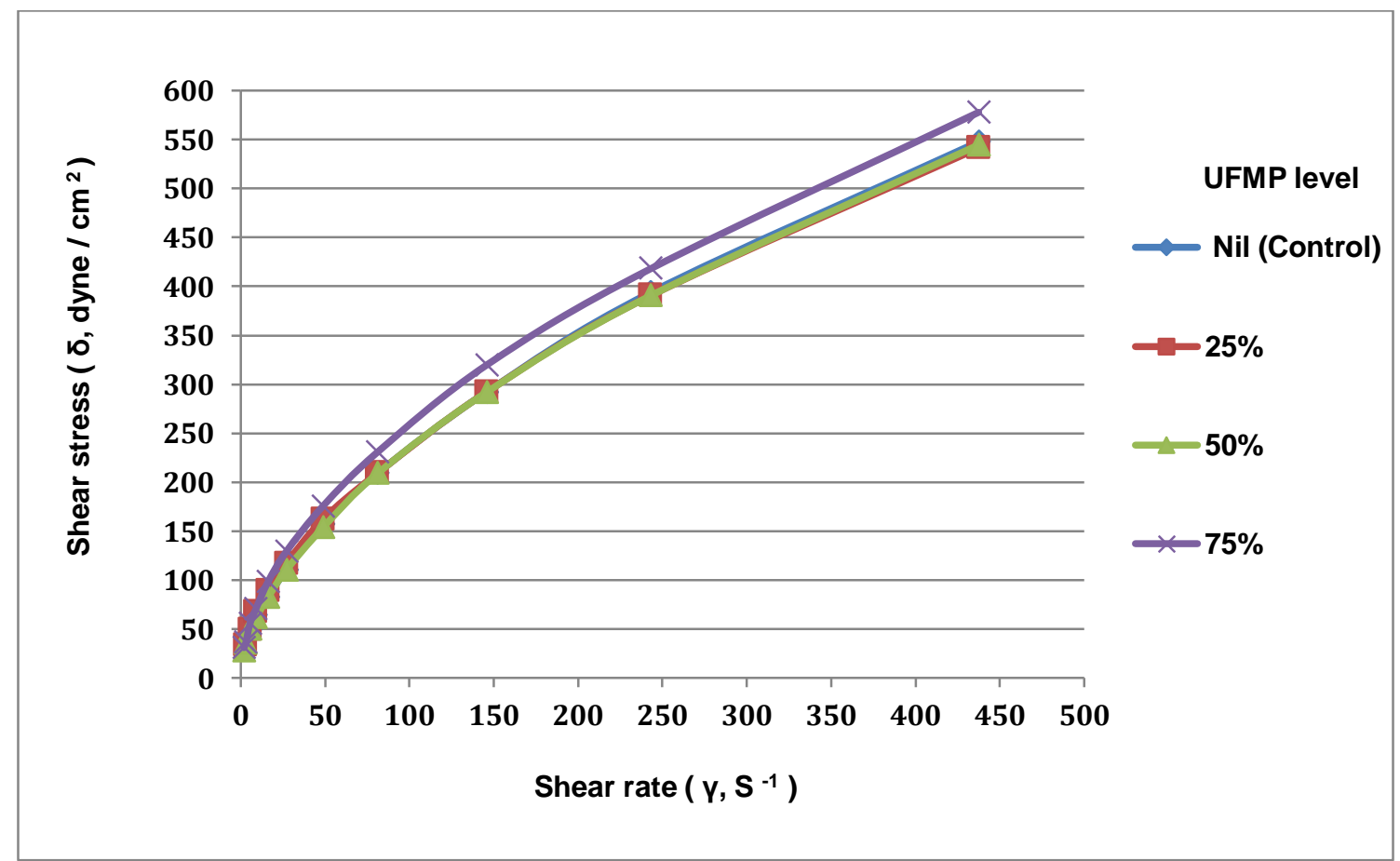

Fig. 2. Flow curves of control and experimental mango Sherbet mixes (containing pumpkin solids and UFMP) 

solids and uf milk permeate

\begin{abstract}
Melting loss\% (i.e. melting resistance of product) was assessed at various intervals of $15 \mathrm{~min}$., starting at $15 \mathrm{~min}$. till complete melting (i.e. $45 \mathrm{~min}$.) The values of melting loss (\%) of frozen Sherbet mix tended to decrease as the replacement level of water with UFMP was increased (Table, 6). Similarly, for Sorbet, the melting loss (\%) was lowered (less melting) when the replacement level of water portion of mix with UFMP was increased. It is of interest to note that complete melting loss $(100 \%)$ took place at $30 \mathrm{~min}$ for control Sorbet as shown in the same Table 6. The positive effect of water replacement with UFMP can be explained by increasing the product's resistance to melting by looking at the freezing point of the mix, which decreases as the UFMP portion increases (Table, 4). This means that there is an inverse relationship between the freezing point of the mix and the resistance of the resulting frozen product to melting. In this respect, it is worthy to explain that, there are two opposing forces occurs for melting resistance, (i) FP, (ii) mix viscosity. The increase in mix viscosity (with greater replacement level with UFMP in specific product) was greater than the lowering in FP - hence obtain greater melting resistance in that product!). Similar findings have been reported and discussed by Fayed et al (2012). The Sherbet is associated with greater resistant to melting as compared to Sorbet, when same level of replacement of water with UFMP is considered.
\end{abstract}

The curves drawn in the Fig. 4 demonstrate the extent of the correlation in the ascending relationship between the level of replacement of mix water with UFMP and the level of TS and dynamic viscosity in the final product; be it Sherbet or Sorbet. The proportional water substitution of mixes with UFMP led to a gradual increase in both TS and dynamic viscosity of the resultant mixes. Generally, similar observations, towards the relation between TS and viscosity of mixes whether of ice cream made using UF-skimmed milk retentate versus UF-whey protein concentrate or frozen yoghurt, have been reported and discussed by Fayed et al (2012). Moreover, it is worthwhile to mention that Sherbets possessed higher values of dynamic viscosity as compared to Sorbets, when compared at specific level of water substitution with UFMP in relevant mixes (Fig. 4). This suggests that the protein supplied by presence of SMP (about 35\% protein) in Sherbet mixes, conferred the desired viscosity as compared to the increased sugar (5\% higher than in Sherbet, but devoid of milk solids) present in Sorbet mixes.

\section{Sensory quality of Sherbet or Sorbet}

The sensory scores of Sherbet or Sorbet confirmed use of UFMP to replace up to $50 \%$ of water in the mix, failed to significantly $(P>0.05)$ affect the consistency score of both products. At the maximum level of replacement of water with UFMP (i.e. $75 \%$ level), frozen dessert (whether Sherbet or Sorbet) had higher $(P<0.05)$ mean score for consistency when compared to which the control or even product with 25 and $50 \%$ replacement levels.

Irrespective of the type of frozen dessert (i.e. Sherbet, Sorbet), the product made using maximum level of water replaced with UFMP (i.e. $75 \%$ ) was associated with higher mean flavor score $(\mathrm{P}<0.05)$ as compared to those having lower replacement levels $(25,50 \%)$ and control product. The sensory scores for Sherbets and Sorbets depicted in Table 7 reveals that, products prepared using UFMP at $50 \%$ replacement level and control (no replacement of water) had flavor scores that was at par with each other. It is worthy to mention that, the mango used was rich in flavor so that the taste of added pumpkin was completely masked, especially since the percentage of mango pulp substitution with it did not exceed $10 \%$ as it was deliberately designed in advance in the previous work of mango drink carried out by Eid et al (2019).

Likewise, superior melting quality score was noted for Sherbet or Sorbet prepared using UFMP used at $75 \%$ level of water replacement $(P<0.05)$ as compared to those having lower replacement levels $(25,50 \%)$ and control product (Table, 7$)$. The melting quality in the mouth is considered a key sensory feature; whereas the mouth feels the resulting frozen product as was clearly demonstrated through sensory arbitration.

Since the frozen desserts (Sherbets, Sorbet) prepared using maximum level of UFMP (i.e. $75 \%$ replacement for water portion of mixes) had significantly $(P<0.05)$ superior scores for consistency, flavor and melting quality, such products had significantly $(\mathrm{P}<0.05)$ greater score for total sensory score when compared to other products ( 25 and $50 \%$ replacement of water, and control product). 


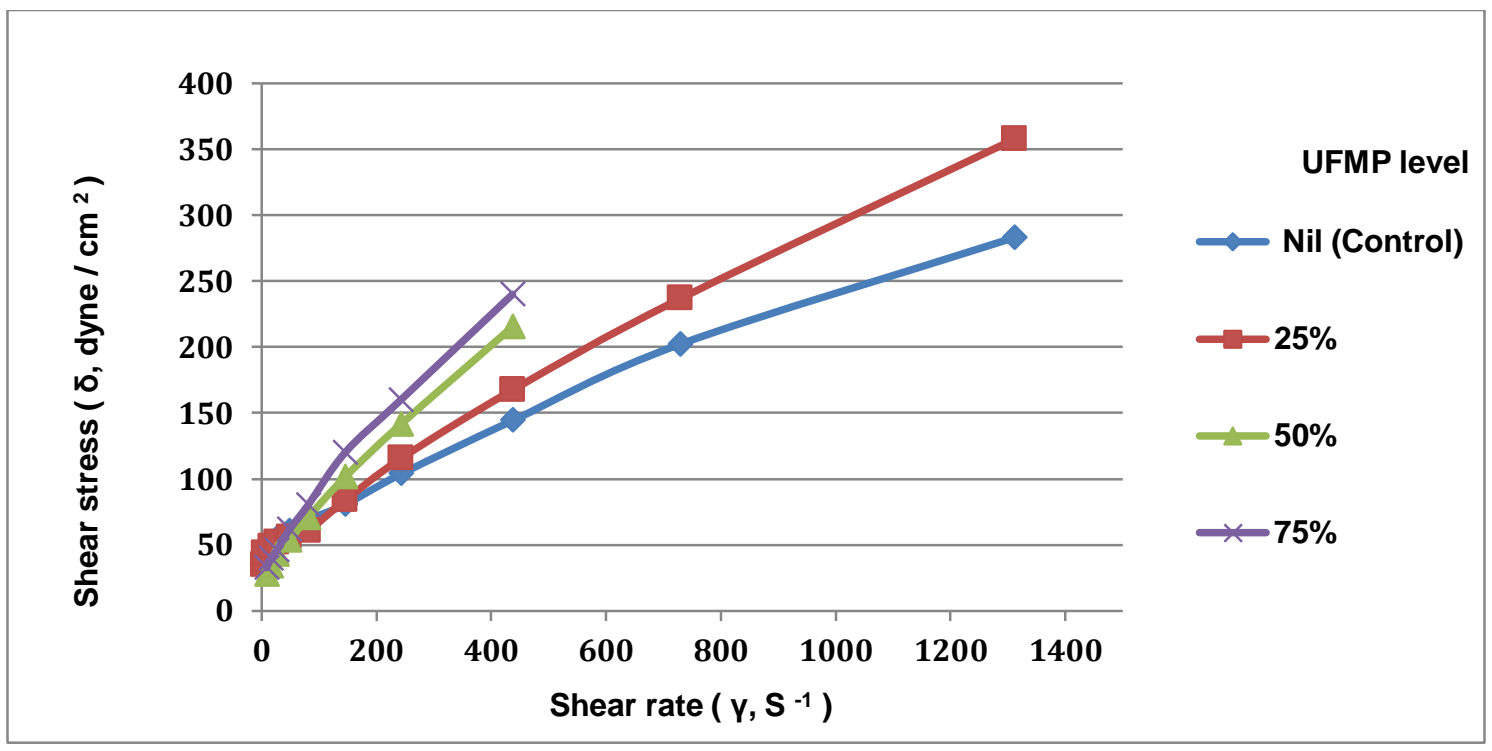

Fig. 3. Flow curves of control and experimental mango Sorbet mixes (containing pumpkin solids and UFMP)

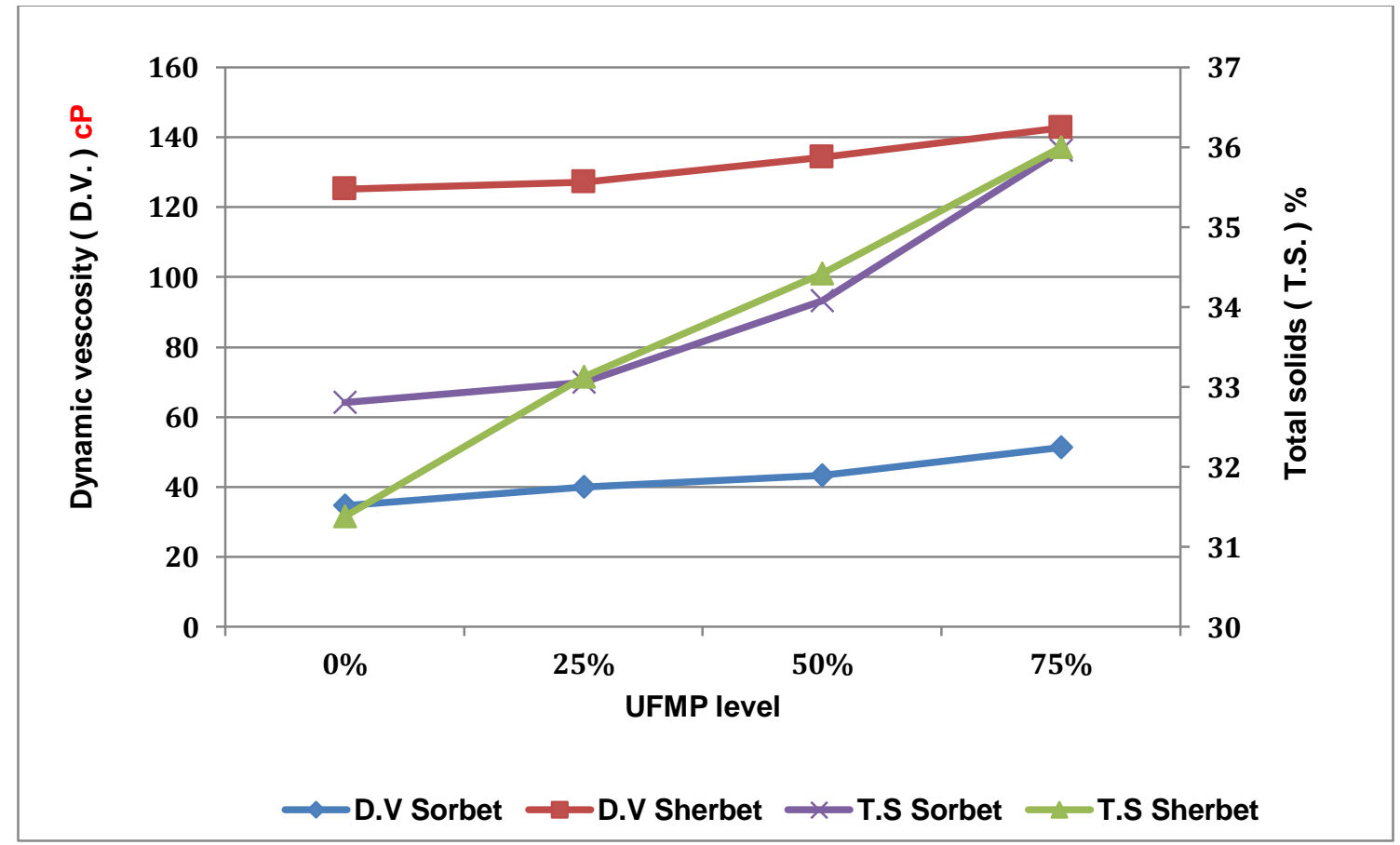

Fig. 4. Dynamic viscosity (cP) and TS content of control and experimental mango Sherbets and Sorbets mixes as affected by the presence of pumpkin solids and UFMP 

solids and uf milk permeate

Table 6. Physical properties of frozen mango Sherbet or Sorbet fortified with $1 \%$ cooked pumpkin as affected by water replacement level with ultrafiltered milk permeate (UFMP)

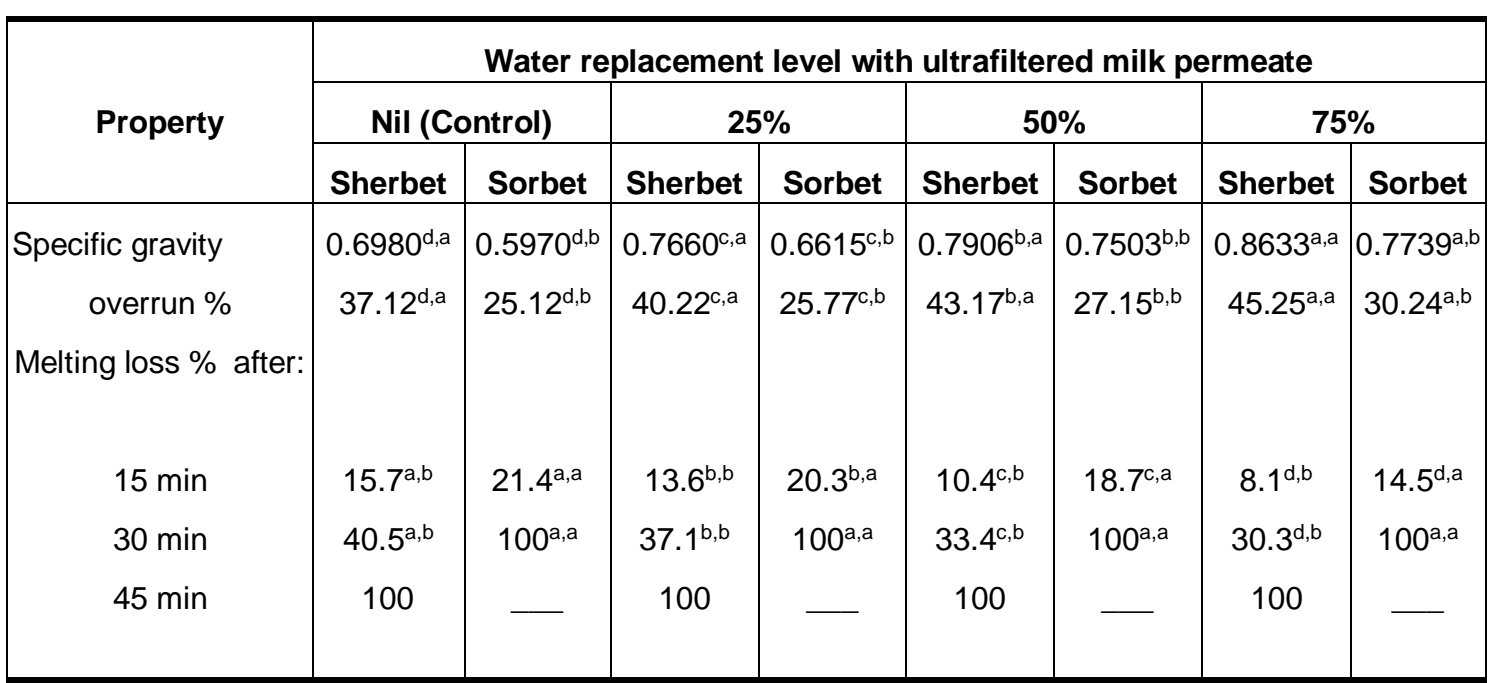

The letters before comma possess the factor of water replacement with UFMP. While those after comma possess the factor of the kind of dairy frozen dessert mix, respectively. The means with the same letter at any position did not significantly differ $(P>0.05)$.

Table 7. Sensory scores of frozen mango Sherbet or Sorbet fortified with $1 \%$ cooked pumpkin as affected by water replacement level with ultrafiltered milk permeate (UFMP)

\begin{tabular}{|c|c|c|c|c|c|c|c|c|}
\hline \multirow{2}{*}{ Sensory attribute } & \multicolumn{5}{|c|}{ Water replacement level with ultrafiltered milk permeate } \\
\cline { 2 - 8 } & \multicolumn{2}{|c|}{ Nil (Control) } & \multicolumn{2}{|c|}{$25 \%$} & \multicolumn{2}{|c|}{$50 \%$} & \multicolumn{2}{c|}{$75 \%$} \\
\cline { 2 - 8 } & Sherbet & Sorbet & Sherbet & Sorbet & Sherbet & Sorbet & Sherbet & Sorbet \\
\hline $\begin{array}{c}\text { Consistency } \\
\text { (out of } 40 \text { point) }\end{array}$ & $35.90^{\mathrm{b}, \mathrm{a}}$ & $35.00^{\mathrm{b}, \mathrm{a}}$ & $35.20^{\mathrm{b}, \mathrm{a}}$ & $32.80^{\mathrm{b}, \mathrm{b}}$ & $35.80^{\mathrm{b}, \mathrm{a}}$ & $33.90^{\mathrm{b}, \mathrm{b}}$ & $37.90^{\mathrm{a}, \mathrm{a}}$ & $38.40^{\mathrm{a}, \mathrm{a}}$ \\
$\begin{array}{c}\text { Flavor } \\
\text { (out of } 50 \text { point) }\end{array}$ & $44.60^{\mathrm{b}, \mathrm{a}}$ & $42.50^{\mathrm{b}, \mathrm{b}}$ & $42.00^{\mathrm{b}, \mathrm{a}}$ & $42.10^{\mathrm{b}, \mathrm{a}}$ & $43.70^{\mathrm{b}, \mathrm{a}}$ & $42.10^{\mathrm{b}, \mathrm{a}}$ & $47.50^{\mathrm{a}, \mathrm{a}}$ & $48.60^{\mathrm{a}, \mathrm{a}}$ \\
$\begin{array}{c}\text { Melting quality } \\
\text { (out of } 10 \text { point) }\end{array}$ & $8.60^{\mathrm{b}, \mathrm{a}}$ & $8.40^{\mathrm{b}, \mathrm{a}}$ & $8.20^{\mathrm{b}, \mathrm{a}}$ & $7.80^{\mathrm{b}, \mathrm{b}}$ & $8.60^{\mathrm{b}, \mathrm{a}}$ & $8.10^{\mathrm{b}, \mathrm{a}}$ & $9.40^{\mathrm{a}, \mathrm{a}}$ & $9.50^{\mathrm{a}, \mathrm{a}}$ \\
$\begin{array}{c}\text { Overall acceptability } \\
\text { (out of } 100 \text { point) }\end{array}$ & $89.10^{\mathrm{b}, \mathrm{a}}$ & $85.90^{\mathrm{c}, \mathrm{b}}$ & $85.40^{\mathrm{c}, \mathrm{a}}$ & $82.70^{\mathrm{c}, \mathrm{a}}$ & $88.10^{\mathrm{b}, \mathrm{a}}$ & $84.10^{\mathrm{c}, \mathrm{a}}$ & $94.80^{\mathrm{a}, \mathrm{a}}$ & $96.50^{\mathrm{a}, \mathrm{a}}$ \\
\hline
\end{tabular}

The letters before comma possess the factor of water replacement with UFMP. While those after comma possess the factor of the kind of dairy frozen dessert mix, respectively. The means with the same letter at any position did not significantly differ $(P>0.05)$. 
Table 8. Antioxidant activity of mango Sherbet or Sorbet mix with $1 \%$ cooked pumpkin as affected by water replacement level with ultrafiltered milk permeate (UFMP)

\begin{tabular}{|c|c|c|c|c|c|c|c|c|}
\hline \multirow{2}{*}{ Property } & \multicolumn{5}{|c|}{ Water replacement level with ultrafiltered milk permeate } \\
\cline { 2 - 8 } & \multicolumn{2}{|c|}{ Nil (Control) } & \multicolumn{2}{c|}{$25 \%$} & \multicolumn{2}{c|}{$50 \%$} & \multicolumn{2}{c|}{$75 \%$} \\
\cline { 2 - 8 } & Sherbet & Sorbet & Sherbet & Sorbet & Sherbet & Sorbet & Sherbet & Sorbet \\
\hline $\begin{array}{c}\text { Total phenolic } \\
\text { (mgGAE/g) } \\
\begin{array}{c}\text { Total flavonoids } \\
\text { (mg QE /g) }\end{array}\end{array}$ & $9.49^{\mathrm{d}, \mathrm{a}}$ & $8.27^{\mathrm{d}, \mathrm{b}}$ & $10.32^{\mathrm{c}, \mathrm{a}}$ & $9.10^{\mathrm{c}, \mathrm{b}}$ & $11.15^{\mathrm{b}, \mathrm{a}}$ & $9.93^{\mathrm{b}, \mathrm{b}}$ & $11.98^{\mathrm{a}, \mathrm{a}}$ & $10.76^{\mathrm{a}, \mathrm{b}}$ \\
$\begin{array}{c}\text { DPPH radical scavenging } \\
\text { activity \% }\end{array}$ & $24.37^{\mathrm{a}, \mathrm{a}}$ & $23.93^{\mathrm{a}, \mathrm{a}}$ & $24.45^{\mathrm{a}, \mathrm{a}}$ & $24.01^{\mathrm{a}, \mathrm{a}}$ & $24.52^{\mathrm{a}, \mathrm{a}}$ & $24.08^{\mathrm{a}, \mathrm{a}}$ & $24.59^{\mathrm{a}, \mathrm{a}}$ & $24.15^{\mathrm{a}, \mathrm{a}}$ \\
\hline
\end{tabular}

The letters before comma possess the factor of water replacement with UFMP. While those after comma possess the factor of the kind of dessert mix, respectively. The means with the same letter at any position did not significantly differ $(P>0.05)$.

Physiological advantages resulting from the incorporation of UFMP towards the antioxidant activity

The results present in Table 8 revealed that, although TF was not influenced, the proportional water substitution with UFMP caused significantly gradual increment in both TP and RSA values either of Sherbets or Sorbets. Moreover, Sherbets were always distinguished from Sorbets with their significant high RSA \%. That could be ascribed to the presence of SMP in their recipe, which possessed a considerable protein reducing value. Similar confirmations were done by Hofi et al (1983).

\section{CONCLUSION}

The forgoing results led satisfactory to conclude that, it could be successfully produced Sherbet or Sorbet using $9 \%$ mango plus $1 \%$ cooked pumpkin; as valuable addition; and furtherly water replacement with $75 \%$ ultrafiltered milk permeate, those of many impressive health benefits to meet the intended health purposes, consequentialist according to the sensory acceptability, those en route to innovate frozen desserts. This ensures that the product is supplied through such natural additional sources of antioxidant activity to elevate its physiological benefits and en route to innovate products.

\section{REFERENCES}

Aamer R.A., El-Kholy W.M. and Mailam M.A. (2017). Production of functional beverages from whey and permeate containing kumquat fruit. Alex. J. Fd. Sci. \& Technol., 14, 41-56.
AOAC (2012). Association of Official Analytical Chemists. Official methods of analysis of AOAC International, $19^{\text {th }}$ ed., Benjamin Franklin, Washington D.C., USA. pp. 302-850.

Bourne M.C. (1982). In: Food Texture and Viscosity - Concept and Measurement. Academic press Inc., New York, USA, pp. 240-244.

Brand-Williams W., Cuvelier M.E. and Berset C. (1995). Review article: Use of a free radical method to evaluate antioxidant activity. Lebensmittel-Wissenschaft und -Technologie (LWT) - Food Sci. Technol. 28, 25-30.

BSI (1990). British Standards Institution. Testing aggregates. General requirements for apparatus and calibration. BS 812: Part 100, BSI, London, UK.

Charles C. (2010). Phenol-sulfuric acid method for total carbohydrates. In: Food Analysis Laboratory Manual (Nielsen, S.S., Ed.), $2^{\text {nd }}$ Ed. Chap. (6), pp. 47-53. Springer-Verlag, USA.

Code of Federal Regulations (2018). Title 21: Food and Drugs, Part 135 -- Frozen Desserts. Subpart B--Requirements for Specific Standardized Frozen Desserts. Sec. Water Ices. pp. 135160.

Dragana D., Milanovic S. and Ilicic M. (2013). Permeate components valorization for beverage manufacturing. Agro Food Industry Hi Tech., 4, 24-27.

Eid M.I., Fayed A.E., Khallaf M.F. and Abo ElNaga M.Y. (2019). Utilization of ultrafiltered milk permeate as water substitute in mango drink fortified with pumpkin cubes en route to innovative a functional drink. Arab Univ. J. Agric. Sci. Ain Shams Univ., Cairo, Egypt, 27, 2583-2592. 

solids and uf milk permeate

EOSQ (2005a). Egyptian Organization for Standardization and Quality. Milk and Water Ice (Ice Cream). Part: I. Milk Ice. Egyptian Standards (ES): 1185-1/2005. pp. 3-5.

EOSQ (2005b). Egyptian Organization for Standardization and Quality. Milk and Water Ice (Ice Cream). Part: II. Water Ice. Egyptian Standards (ES): 1185-2/2005. pp. 3-5.

FAO (1977). Food and Agriculture Organization. Regional Dairy Development and Training Center for the Near East. Laboratory Manual Spring (1977).

Fayed A.E. (1986). Protein fortification of some dairy products. Ph.D. Thesis, Fac. of Agric., Ain Shams Univ., Cairo, Egypt. pp. 30-52.

Fayed A.E., Metwally A.I., Essawy E.A. and Tawfek M.A. (2012). Application of ultrafiltration technique in the manufacture of reduced-calorie frozen bioyoghurt in synbiotic form. Proc. 11 ${ }^{\text {th }}$ Conf. Agric. Dev. Res., Ain Shams Univ., Cairo, Mar., 27-30, Ann. Agric. Sci., Sp. Issue, 58, 315-331.

Goff H.D. and Hartel R.W. (2013). Calculation of ice cream mixes. In: Ice Cream. $7^{\text {th }}$ Ed. Springer Science Business Media New York. U.S.A. pp. 155-191.

Gong L., Paris H.S., Nee M.H., Stift G., Pachner M., Vollmann J. and Lelley T. (2012). Genetic relationships and evolution in Cucurbita pepo (pumpkin, squash, gourd) as revealed by simple sequence repeat polymorphisms. Theor. Appl. Genet., 124, 875-891.

Hattem H.E.A., Abouel-Einin E.H. and Mehanna N.M. (2010). Utilization of milk permeate in manufacture of sports drinks. J. Food and Dairy Sci., 1, 735-742.

Hofi A.A., Hagrass A.E., Asker A.A., Fayed A.E. and Haggag H.F. (1983). Qualitative and quantitative detection of milk powder in some dairy products. Proc. $6^{\text {th }}$ World Congr. Food Sci. \& Technol., Dublin, Sept., Vol. II, 64.

Khansari N., Shakiba Y. and Mahmoudi M. (2009). Chronic inflammation and oxidative stress as a major cause of age-related diseases and cancer. Recent Pat. Inflamm. Allergy Drug Discov., 3, 73-80.

Lotfy T.M.R., Mahfouz M.Z. and Youssef M.M. (2017). Effect of different cooking methods on natural antioxidants in pumpkin (Cucurbita moschata) products. Alex. J. Fd. Sci. \& Technol., 14, 17-24.
Marshall R.T., Goff H.D. and Hartel R.W. (2003). Sherbets, sorbets and ices. In: Ice Cream. Springer Science + Business Media New York. pp. 265-274. Originally publ. by Kluwer Academic/Plenum Publ., New York, USA.

Mohdaly A.A.A., Hassanien M.F.R., Mahmoud A., Sarhan M.A. and Smetanska I. (2012). Phenolics extracted from potato, sugar beet, and sesame processing by-products. Int. J. Food Properties, 16, 1148-1168.

Muralidhara B.M., Veena G.L., Bhattacherjee A.K. and Rajan S. (2019). Antioxidants in ripe peel and pulp of twelve mango (Mangifera indica) cultivars. Ind. J. Agric. Sci., 89, 15801584.

Muse M.R. and Hartel R.W. (2004). Ice cream structural elements that affect melting rate and hardness. J. Dairy Sci., 87, 1-10.

Pullar J.M., Carr A.C. and Vissers M.C.M. 2017. The Roles of vitamin C in skin health. Nutrients, 12, 9.

Rizk A.E. 2016. Study of production functional beverages of milk permeate fortified with fruit and herbs. Middle East J. Applied Sci., 6, 155-161.

Rothwell J. 1960. Recent ice cream research (1954 - 1959). Dairy Sci. Abstr., 22, 483-494.

SAS 2006. Statistical Analysis System. SAS user's guide. Statistics. SAS Inst. Inc. $4^{\text {th }} \mathrm{Ed}$, Cary, NC, USA.

Singleton V.L., Orthofer R. and LamuelaRavento's R.M. 1999. Analysis of total phenols and other oxidation substrates and antioxidants by means of Folin-Ciocalteu reagent. Methods in Enzymol. 299, 152-178.

Sommer H.H. 1951. Freezing the ice cream. In: The Theory and Practice of Ice Cream Making (edited by H.H. Sommer). Milwaukee, Olsen Publishing Company, pp. 286-289.

Toledo R.T. 2007. Flow of fluids. In: Fundamental of Food Process Engineering. $3^{\text {rd }}$ Ed., Springer Science Business Media LLC pub., USA, pp. 153-221.

Veldhoen M. and Ferreira C. 2015. Influence of nutrient-derived metabolites on lymphocyte immunity. Nat. Med., 21, 709-718.

Vinceti M., Filippini T., Crippa A., de Sesmaisons A., Wise L.A. and Orsini N. 2016. Metaanalysis of potassium intake and the risk of stroke. J. Amer. Heart Assoc., 6, pii: e004210.

Zhou Y., Wang T., Meng Q. and Zhai. S. 2016. Association of carotenoids with risk of gastric cancer: A meta-analysis. Clin. Nutr., 35, 109116. 
مجلة اتحاد الجامعات العربية للعلوم الزراعية، جامعة عين شمس، القاهرة، مصر

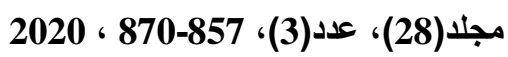

$$
\text { قسم علوم الأغذية - كلية الزراعة - جامعة عين شمد يوسف أبو النجا" - محمد فرج خلاف - مروة ابراهيم عيد } 68 \text { - حدائق شبرا } 11241 \text { - القاهرة - مصر }
$$

*Corresponding author: mohamedyousef@agr.asu.edu.eg

مؤشر سلوك التذفق لم يتأثر في المشروبات اللبنية

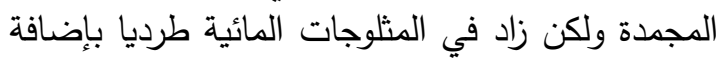

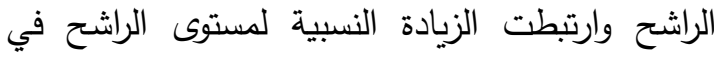

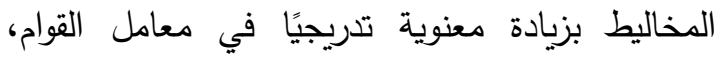

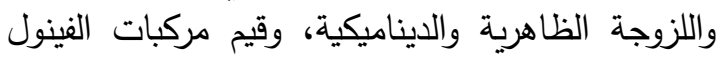
الكلية ونشاط مسك الشوارد لكلا من المشروبات اللانيات اللبنية

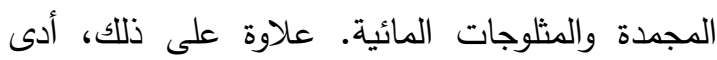

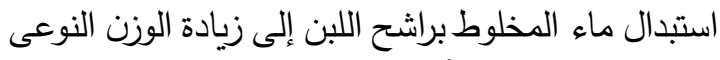

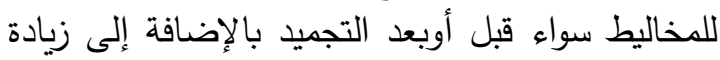

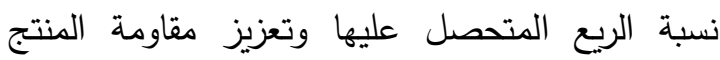

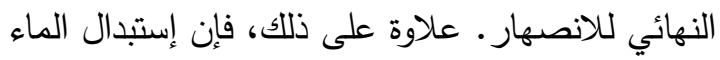

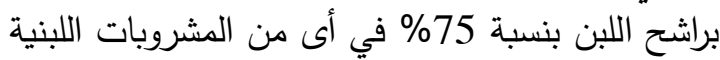

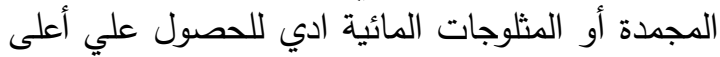

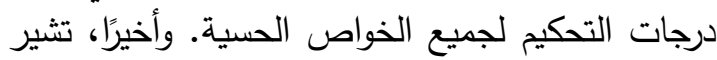

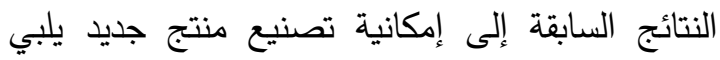

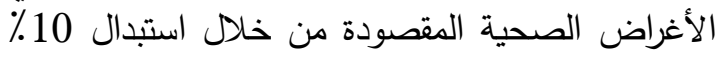

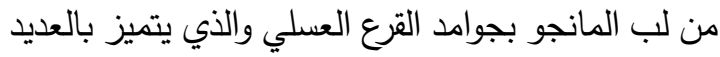

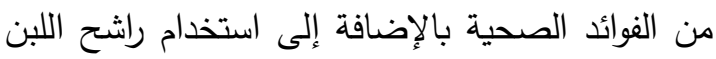

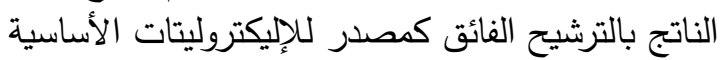

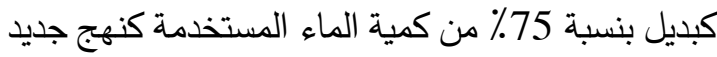
لانتاج حلوى مجمدة مثل المشروبات اللبنية المجمدة

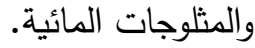

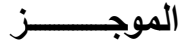

تم إعداد مشروبات للنية مجمدة (جرانيتا اللبن) ومثلوجات مائية (الجرانيتا) من النوع المنكهه بالفاكهة

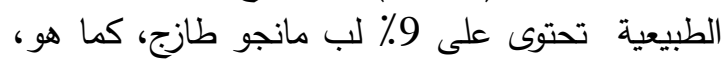

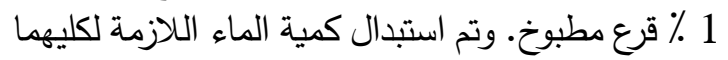
براشح اللبن الناتج بالترشيح الفائق بنسب التبد 25 أو 50 أو الو

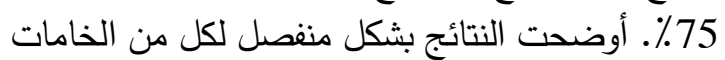
الرئيسبة المستخدمة ، احتواء القرع المطبوخ على نسب التبات

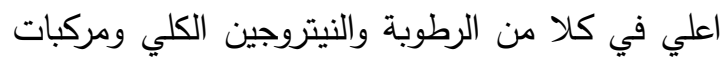
الفينول الكلية بالإضافة إلى قيم نشاط الثربة مسك (كسح) الثوارد ونسب أقل في مركبات الفلافونويد الكلية ومحتوي الكربوهيدرات مقارنة بلب المانجو • في حين ادي استبدال

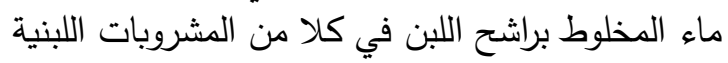

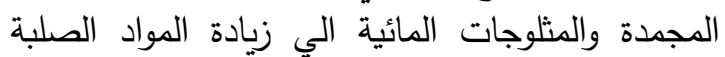

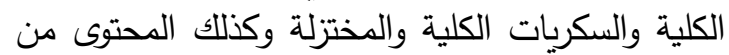

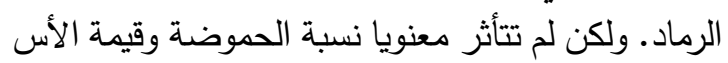

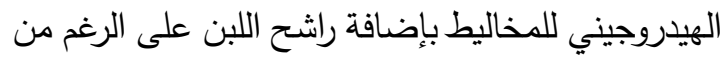

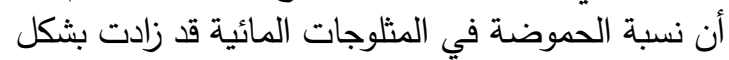

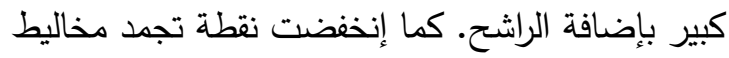
المشروبات اللبنية المجمدة والمثلوجات المائية تدريجيًا

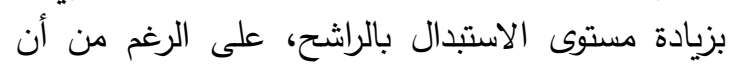

